\title{
The abnā' al-dawla: The Definition and Legitimation of Identity in Response to the Fourth Fitna
}

John P. Turner

Colby College, jpturner@colby.edu

Follow this and additional works at: https://digitalcommons.colby.edu/faculty_scholarship

Part of the Islamic World and Near East History Commons

\section{Recommended Citation}

Turner, John P., "The abnā' al-dawla: The Definition and Legitimation of Identity in Response to the Fourth Fitna" (2004). Faculty Scholarship. 69.

https://digitalcommons.colby.edu/faculty_scholarship/69 


\title{
The $a b n \bar{a}^{\prime}$ al-dawla: The Definition and Legitimation of Identity in Response to the Fourth Fitna
}

\author{
JOHN P. TURNER \\ KENNESAW STATE University
}

This article will reopen the question about the identity and provenance of the $a b n \bar{a}>a l$ dawla. Who were they? When did they form as a collective and why? The standard view is that the $a b n \bar{a}$ ) al-dawla were the backbone of the Abbasid dynasty, coming into existence with that regime after the revolution circa 132/750 and consisting of the original fighters from Khurasan and their descendants, who formed an elite social and political structure of supporters. This privileged status accorded them the moniker $a b n \vec{a}^{\prime}$ al-dawla (sons/supporters of the dynasty).

Recent scholarship on premodern Islamic history typically allows modern conceptualizations of identity to determine the understanding of group dynamics and identity formation. However, these typically are not applicable to the third/ninth century. ${ }^{1}$ The abna $\vec{a}$ al-dawla are particularly in need of reinterpretation. ${ }^{2}$ Still, determining who they were presents a number of difficulties. The blanket term $a b n \bar{a}^{\prime}$, as it is most often used, leaves little room, in its monolithic presentation as an ethnic or nationality based group, for the subtleties of social interaction. One must not forget that the $a b n \bar{a}^{\prime}$ al-dawla as a political actor was made up of individuals with many other ties of identity. In the course of this article I will show that it was during the fourth fitna (195/810-198/813) that these individuals formed an identity for collective action. This is not based on ethnic or national affinity. Reading the sources closely reveals that they do not appear as a coherent group until that conflict, and they disappear shortly thereafter.

Scholars have taken a variety of terms as synonymous with $a b n \bar{a}^{\prime}$ al-dawla that actually are not. When the military units were settled in Baghdad at its founding, they were grouped roughly by region of origin representing a great diversity of locales. ${ }^{3}$ Garrisoning troops in this manner does not necessarily translate into settlement by ethnic or national identity, nor does it lead to the creation of these identities. ${ }^{4}$ When hostilities broke out between al-Amin

An early version of this article was presented to the 1999 annual meeting of MESA. Subsequently revised, it appeared in my "Inquisition and the Definition of Identity in Early Abbasid History" (Ph.D. diss., University of Michigan, 2001). The present article draws upon both of those but has changed significantly due to helpful comments and criticisms at each previous stage.

1. See M. Rowlands, "The Politics of Identity in Archaeology," in Social Construction of the Past, ed. G. C. Bond and A. Gilliam (London: Routledge, 1994), 130; also D. McCrone, The Sociology of Nationalism (London: Routledge, 1998), 23-24.

2. Crone notes in reference to several individuals, "They are often described as $A b n \bar{a}$ ' in the secondary literature, but this merely goes to show that modern scholars routinely extend the Banawi label to all offspring of the participants in the revolution." P. Crone, "The 'Abbāsid Abnā' and Sasanid Cavalrymen," Journal of the Royal Asiatic Society 8 (1998): 5.

3. M. Sharon, Revolt: The Social and Military Aspects of the 'Abbāsid Revolution (Jerusalem: Hebrew Univ., 1990), 263-301.

4. McCrone, Sociology of Nationalism, 23. "Such identifiers of ethnicity, however, do not automatically generate an 'identity', because the key will be how an individual chooses to identify with these characteristics. 'Identity' is perception. If a particular identity does not mean anything to the population in question, this population does not 
and al-Ma'mūn, individuals rose to fight based on horizontal ties of loyalty, which focused vertically on the caliph and anti-caliph. These ties were not based on a shared sense of ethnicity or nationalism but rather on linkages of local commonality, meaning quarters, bonds of patronage, and perceptions of common interests. In the process of asserting a threat or in responding to it, the various players on the field were forced to seek justification for their places and roles. They were Khurasanians (al-Ma'mūn's forces mostly from Khurasan) facing people whose familial roots were in Khurasan but who resided in Baghdad. ${ }^{5}$ The defining connection for the $a b n \vec{a}$ ' al-dawla was location in Baghdad. They were proud of having come from Khurasan and claimed some sense of "Khurasaniness," but their use of the term clearly excluded Tâhir and the forces of al-Ma'mūn. One side actively tried to dissociate itself from the other. ${ }^{6}$ In this process of dissociation, the $a b n \bar{a}$ ' al-dawla came to define themselves in opposition to the others, who happened to be the rabble of Baghdad and the followers of alMa'mūn who was proclaiming a new $d a^{c} w a$. The latter were fighting for the new $d a^{\boldsymbol{c}} w a$ and were held together by their own special ties of loyalty and patronage. Al-Ma'mūn's primary general, Tāhir b. al-Husayn, exhorts his troops: "Oh friends of God and people of fidelity and gratitude, verily you are not such as those you see of the people of faithlessness and treason. They neglected what you preserved. They belittled what you esteemed. They were faithless to the oaths that you guarded ..."7 At the same time elite members of Baghdad society sought justification for their place by asserting that they were the $a b n \bar{a}^{\prime}$ al-dawla, sons of the first supporters of the original $d a^{\boldsymbol{}} w a$, tightly connected to the caliph and to the Abbasid household. Within the Baghdad milieu, the vertical bonds of loyalty and assertion of ties to the Caliph and caliphal household brought disparate individuals into a larger body for collective action. The new $d a^{\prime} w a$ of al-Ma'mūn, the approach of his forces and the siege, caused the $a b n \bar{a}^{\prime}$ al-dawla to coalesce in an assertion of their unique position. However, their interests and loyalties were too diffuse to form an effective, unified military body, especially once the unifying identifier and its utility had been removed. This political subscription to an identity by a group of military supporters of the Abbasid caliphate was defined by focusing on, and in terms of, "historical" loyalty to that caliphate and the caliphate's "historical" ties to them. The idiom in which they chose to express this allows for the description of a collective grouping but not of one that was as pervasive, cohesive, or as old as has been assumed.

\section{PREVIOUS DEFINITIONS}

In 1964, David Ayalon presented the paper “The Military Reforms of Caliph al-Mu'tașim," which even though it was not formally published until thirty years later, has set the tone for the field and its understanding of the $a b n \vec{a}^{\prime}$ al-dawla and consequently of early Abbasid history. ${ }^{8}$ Even though unpublished, it was passed around and took on an almost primary source-

have this particular identity." And p. 28: "The key point here is that there is no one-to-one relationship between ethnicity and cultural identifiers. What matters is which ones key actors regard as significant, for which purposes and under which conditions." And quoting Eriksen on the same page "It is only when they make a difference that cultural differences are important in the creation of ethnic boundaries."

5. An analogous situation would be the American colonists vs. the British in the American Revolution.

6. See M. Bonner, "Definitions of Poverty and the Rise of the Muslim Urban Poor," Journal of the Royal Asiatic Society 6 (1996): 336.

7. Abū Ja'far Muhammad b. Jarīr al-Ṭabarī, Ta'rīkh al-rusul wa'l-mulūk, ed. M. J. de Goeje, 15 vols. (Leiden: E. J. Brill, 1879), 3: 823.15-17.

8. Ayalon, "The Military Reforms of Caliph al-Mu'tașim," in Islam and the Abode of War (Norfolk: Variorum, 1994). 
like status. Brilliant in its erudition, Ayalon's fundamental understanding of the group and its social dynamic is nevertheless flawed because of his assumptions about their national and ethnic identity which led to the notion that it was a coherent political actor from the beginning-an interpretation that has become the norm.

Ayalon's definition of the $a b n \bar{a}$ ' as "the descendants of the Khurāsānīs who brought the 'Abbāsids to the throne, and who included both Iranians and Arabs" forms a foundation for almost all studies of the early Abbasids. ${ }^{9} \mathrm{He}$ considers the $a b n \vec{a}$ ' to have been an ethnically based coterie, which was then transplanted to Baghdad. This means that while the Arabs and the Iranians were "racially" distinct from each other, they felt, by virtue of their common origin in Khurasan, an ethnic unity. In the course of his article, Ayalon highlights the tribal struggles out of which Abü Muslim and his fighters emerged as victors. He then compares this with the army of al-Ma'mūn, which he says was made up of "racial elements" that were definitely not Arab. ${ }^{10}$ In 1990 Moshe Sharon refined this by adding that the original Abbasid army was much more diverse than Ayalon allows. The limiting factor was, according to Sharon, registration according to village and not by tribe. ${ }^{11}$ For Ayalon the leadership cadre of the Abbasid revolution was made up of Arabs who had migrated to Khurasan. ${ }^{12}$ However he also reads the $a b n \vec{a}^{\prime}$ as having explicit ties to each other and to their home region of Khurasan based on their common "national" origin. ${ }^{13}$ Amikam Elad goes one step further by stating that the Abbasid military was mostly made up of Arabs from the southern tribes who lived in Khurasan. Thus, they did not represent a resurgence of and takeover of the caliphate by Persians. He assumes the continuity and coherence of their identity as $a b n \vec{a} \mathbf{l} a l$ dawla, but states that they were not Iranians. ${ }^{14}$ Patricia Crone, in her review of Mohsen Zakeri's book, deals skillfully with his theory that the $a b n \bar{a}^{\prime}$ were the descendants of the Sasanian horsemen of Khusraw I. She cuts to the heart of the matter by making the observation that "the $A b n \bar{a}$ ' of the 'Abbāsids owed their name to their descent from the participants in the revolution" and that "there can have been no Abnä' in this sense before the dawla took place." ${ }^{15}$ Underlying each of these are basic assumptions that are rooted in Ayalon's article.

Returning to Ayalon's definition, he notes that they are described as being Baghdadi and quite proud of this, yet at the same time they highlighted their Khurasanian origins. Therefore the $a b n \bar{a}$ ' felt strong, visceral connections to their home region and their "national brothers" living there. Ayalon posits the hypothesis that when Baghdad was built, the Khurasanian troops were all settled in it as an elite corps and their children and grandchildren enjoyed special status and treatment owing to their heritage as early advocates from Khurasan. ${ }^{16}$ Their ethnic identity bound them together. For Ayalon, this identity was based on their shared Arab racial descent which had been turned into a pseudo-Iranian ethnicity that had deepened because of their common locality in Baghdad and their status as a military aristocracy, an

9. Ayalon, "Military Reforms," 6.

10. Ibid., 5 .

11. Sharon, Revolt, 263-301; although not all of the units were so registered.

12. Ayalon, "Military Reforms," 38.

13. Ibid., 8 .

14. Elad, "Aspects of the Transition from the Umayyad to the 'Abbāsid Caliphate," Jerusalem Studies in Arabic and Islam 19 (1995): 89-132.

15. Crone, "'Abbāsid Abnā̄," 3; G. Le Strange, Baghdad during the Abbasid Caliphate (London: Curzon Press, 1972), 128. Le Strange, much earlier, describes the $a b n \vec{a}$ ' as "Persian nobles" "who were already settled in Mesopotamia at the time of the Moslim conquest."

16. Ayalon, "Military Reforms," 8 . His conjecture has become canonical. 
Arabized ethnic group, racially Arab but culturally Khurasanian. Ayalon thus observes that even though they had this distinct connection with Khurasan and pride in this, they are described in the sources as being different from Khurasanians. ${ }^{17}$ In addition, he interprets the $a b n \bar{a}^{\prime}$ as clearly separate from the Arabs. ${ }^{18} \mathrm{He}$ and others are especially bound to the national character of this clique. Elton Daniel says "they had been able to forge and to maintain the revolutionary coalition by appealing to feelings of Khurasanian particularism and a vague form of shî 'ism." ${ }^{19}$ Crone remarks that "generally, the Abna ') were the bodily, as opposed to institutional, descendants of the participants in the revolution" 20 and in a later work that "the sources regularly identified Iranians as $A b n \vec{a}, . "{ }^{21}$ However she does allow that the $a b n \bar{a}$ ' were not wholly "Iranian" or "Arab" but that they were a mixture. ${ }^{22}$ Jacob Lassner argues that there is a clear connection between "the $a b n \bar{a}$ ' and Khurāsān and, hence, a link between the $a b n \vec{a}$ ' and the Turks" and that the $a b n \vec{a}$ ' were the "second generation" of Abbasid revolutionaries. ${ }^{23}$ Crone goes so far as to say "the $A b n \vec{a}$ ' had been designed as an imperial aristocracy." ${ }^{24}$ More recently, she has contrasted them with "Ṭāhir's 'ajam [who] were raw Iranians, people who had failed to transcend their local origins by participation in the high culture." 25 This all seems fairly straightforward but Ayalon makes three observations that are particularly telling and have been largely ignored:

1. The $A b n \bar{a}^{\prime}$ are hardly mentioned before the struggle between Amīn and Ma'mūn. Therefore, the period of their formation and taking shape is completely obscure.

2. Never in their history were the $A b n \vec{a}{ }^{\prime}$ as active as during that struggle.

3. The $A b n \bar{a}^{\prime}$ are stationed exclusively, or almost exclusively, in Baghdad. Practically all the information on them in the chronicles, either during the struggle or after it, is confined to that city. ${ }^{26}$

\section{TERMINOLOGY}

As the preceding discussion shows, in the secondary literature the term $a b n \vec{a}$ ' has been reified as if it had been in common parlance from the beginning of the Abbasid revolution to signify a group founded on almost nationalistic terms. In reality, as Ayalon has partially admitted, the term does not appear in use in this form before the war between al-Amin and al-Ma'mūn. Scholars have assumed that a multiplicity of terms indicate the abna $\bar{a}^{\prime}$ al-dawla, which upon examination do not. Crone states that references to them began during the reign of al-Rashid and that "by far the most common term for the Abbasid troops, whatever their

17. Ibid., 19.

18. Ibid. Concerning the zawaqil incident Ayalon notes that "this is the only occasion on which Khurasani troops are mentioned as fighting for Amīn"; see al-Ṭabarī, Ta'rikkh, 3: 844-45; also Ayalon, "Military Reforms," 12.

19. Daniel, The Political and Social History of Khurasan Under Abbasid Rule 747-820 (Minneapolis: Bibliotheca Islamica, 1979), 58.

20. Crone, Slaves on Horses: The Evolution of the Islamic Polity (Cambridge: Cambridge Univ. Press, 1980), 66.

21. Crone, "Abbāsid Abnā'," 7.

22. Ibid., 11.

23. Lassner, The Shaping of 'Abbāsid Rule (Princeton: Princeton Univ. Press, 1980), 131, 133. Crone picks up the notion that they were the second generation and deploys it with great effectiveness; "The "Abbāsid Abnā'," 3.

24. Crone, Slaves on Horses, 73.

25. "'Abbāsid Abnā'," 14. It is unfortunate that Crone chooses to encode this in terms of nationalist identity, because it is not an essentialized thing that al-Ma'mūn's supporters were all "Iranians," Persians, Turks, or anything else. The assertion being made was that they were outsiders to the community.

26. Ayalon, "Military Reforms," 7. Lassner, Shaping, 133-34, states that "the only certain claim that can be made for the $a b n \bar{a}$ ', before the great civil war between the brothers, is that they are Baghdadis descended from the Khurāsānīs who come to Iraq with the advance of the revolution." 
generation is ahl khurāsān." ${ }^{27}$ It is generally assumed that the terms, "abnä' rijāl al-dawla, baqiyyat rijāl al-da'wa, abnā' ahl khurāsān, abnā' khurāsān, abnā' al-jund al-khurāsāniyya," are synonyms of $a b n \bar{a}^{\prime}$ al-dawla, without reading carefully to see if they in fact are. ${ }^{28}$ In the same way that the thirteenth-century Norman rulers of England are often described as English, ${ }^{29}$ we expect to find the $a b n \bar{a}^{\prime}$ in these terms and so we have. Interestingly, Crone shows how $a b n \bar{a}$ ' of various groups are not identical and that the term $a b n \bar{a}^{\prime}$ can indicate a great range of diversity. ${ }^{30}$ Before proceeding, we should consider these terms and our assumptions about their meanings. A useful place to begin is with a perceived problem with orthography.

Ayalon remarks, "the sources frequently distort $a b n \bar{a}$ ' to anbār and abnāwi to anbārī." 31 Other scholars have taken this to be a truism. ${ }^{32}$ Perhaps Ayalon's desire to see them as a group and this term as referring to the $a b n \bar{a}^{\prime}$ distracted him. Anbār clearly designates a place and $a l-A n b \bar{a} r i$ is the nisba for that place. Located approximately sixty kilometers from Baghdad, al-Saffāh ruled from there for five years. ${ }^{33}$ Of course Ayalon was too careful a scholar to have missed this. What he has done is to assume that the $a b n \bar{a}$ ' as a core elite were already in existence. They went where the caliph went and because al-Saffāh had been there with his Khurasanian forces, the term Anbāri must therefore be synonymous with Abnāwī. Consider that al-Ya'qūbī relates: "and while Abū Ja'far was on the pilgrimage, 'Īsā b. 'Alī received the oath from whomever was from al-Hāshimiyya ${ }^{34}$ and the commanders from al-Anbār . . . then Abū Muslim and whoever was present from al-Hāshimiyya and the commanders took the oath." ${ }^{35}$ Before the founding of Baghdad, al-Saffāh had been ruling from Anbār and naturally these people are designated as living in and being part of the capital. Also notice that those who are from al-Hāshimiyya, where al-Manșūr had ensconced his supporters, are given the nisba Hāshimiyya. This designation, as a parallel, indicates that al-Anbāri is a correct usage. ${ }^{36}$ More tellingly, al-Ya'qūbī in his Kitāb al-Buldān informs us that the Anbārì secretaries were settled in Baghdad. ${ }^{37}$

Elad notes that the person named, 'Abdawayh al-Anbārī, is the victim of "a common orthographical error." ${ }^{38}$ The latter's name should be $a l-A b n \bar{a} w \bar{i}$, but $a l-A n b \bar{a} r \bar{\imath}$ has been substituted by mistake. However, Elad does not produce an instance where the name is rendered as al-Abnāwi ${ }^{39}$ Crone manages to produce a case of the latter that occurs after the fourth

27. "Abbāsid Abnā'," 3.

28. Ibid.

29. B. Anderson, Imagined Communities (New York: Verso, 1991), 118.

30. "'Abbāsid Abnā')" 2-3.

31. Ayalon, "Military Reforms," 33.

32. Crone, "Abbāsid Abnā̄," 9 n. 82: "The Muslim b. Nasr al-A'war al-Anbārī who appears sat Barqa in the time of al-Ma'mūn was presumably also an Abnāwī."

33. J. Lassner, The Topography of Baghdad (Detroit: Wayne State Univ. Press, 1970), 123. He says that it was the capital for only a short time; however, see al-Tabarī, Ta'rīkh, 3: 89, 91-93 (Abū Muslim leaves and takes with him all of the commanders in Anbār); 99, 271 (Al-Manșūr moves the capital from Anbār to al-Hāshimiyya where he and his followers had already settled). Abū Hanīfa Aḥmad b. Dāwūd al-Dīnawarī, Kitāb al-Akhbār al-țiwāl, ed. Abd al-Munim Amir (Cairo: 1960), 390, also shows al-Rashīd spending time in Anbār, bypassing Baghdad.

34. Al-Manșūr had housed his supporters here during the reign of al-Saffāh. Upon ascension he located his capital here for five years before he moved to Baghdad. See al-Ṭabarī, Ta'rikh, 3: 129, 182, 188, 271.

35. Aḥmad b. Abī Ya'qūb b. Ja'far al-Ya'qūbī, al-Ta'rīkh, ed. M. T. Houtsma, 2 vols. (Leiden: E. J. Brill, 1883), 2: 437 .

36. Hāshimiyya is also a tribal nisba, but here it clearly indicates a locality.

37. Aḥmad b. Abī Ya'qūb b. Ja'far al-Ya'qūbī, Kitāb al-Buldān, ed. M. J. de Goeje (Leiden: E. J. Brill, 1892), 245-46. Cited by H. Kennedy, The Armies of the Caliphs (New York: Routledge, 2001), 84.

38. "Aspects of the Transition," 99 n. 47.

39. In all of the texts to which he refers, the individual's name is given either with the nisba al-anbāri or with none. Al-Tabarī, Ta'rīkh, 3: 630, clearly rendered as al-anbārī, p. 1035.7, no nisba is given. 'Izz al-Dīn Ibn al-Athïr, 
fitna ${ }^{40}$ She also cites a few instances in addition to those cited by Elad which she assumes indicate that he is $A b n \bar{a} w \bar{l}$, but which in fact do not. ${ }^{41}$ The rendering al-Anbāri is not an orthographic error. 'Abdawayh is Anbārī, "from the city of Anbār." This does not necessarily mean that he is $A b n \bar{a} w \bar{i}$. The two terms are not interchangeable, nor can we say that it is merely the slip of a copyist's hand that has rendered him such. It appears far too consistently. If one is going to assume that a deviation has occurred, then the preponderance of the evidence points in the opposite direction, that of $a l-A b n \bar{a} w \bar{l}$ being a mistaken rendering of al-Anbāri

Elad also states in the same footnote that the well-known 'Abd al-Rahmān b. Jabala alAbnāwī is sometimes referred to as al-Anbāri and cites al-Tabarī as evidence that this is a mistake. ${ }^{42}$ However, the manuscript says al-Anbārī. The editor in the Addenda et emendana suggests replacing it with $a l-A b n \bar{a} w \bar{l}$, but the source in its original form identifies him as $a l$ Anbārī. This case deserves further consideration, because in al-Tabarī references to this figure identify him as both $a l-A n b \bar{a} r i$ and $a l-A b n \bar{a} w \bar{w}$. He appears three times with the nisba alAnbāri, under the years $185 / 801,195 / 811 .{ }^{43}$ The last time is a brief mention of when he is sent by al-Amin to fight Țāhir. Thereafter his name shifts to al-Abnāwì. The first reference as al-Abnāwi occurs during the year 195/811 as part of a fuller description of his campaign against Țāhir. ${ }^{44}$ However, we should compare this passage with some equivalent passages:

al-Ṭabarī: wajjaha 'Abd al-Raḥmān al-abnāwī fĭ 'ishrin alf rajul min al-abnāa ${ }^{45}$

Ibn al-Athīr: wajjaha 'Abd al-Raḥman b. Jabala al-anbārī fī 'ishrīn alf rajul naḥwa Hamādhan ${ }^{46}$

Was Ibn al-Athīr correcting what he perceived to be a mistake in al-Tabarī? Admittedly Ibn al-Athìr is a much later source, but there is another early parallel in the Fragmenta Historicum Arabicorum which takes a slightly, though informatively, different form:

inna al-Amin qad naffadha 'Abd al-Raḥmān b. Jabala al-anbārī ilä Hamadhān wa qad intakhaba la-hu 'ishrin alf rajul min al-anbār ${ }^{47}$

al-Kāmil fỉ'l-ta'rīkh, ed. 'Abd al-Wahhāb al-Najār (Cairo: Idārat al-Ṭibā'a al-Munīrīya, 1929), 5: 95; he appears as al-anbārī. Khalīfa Ibn Khayyāt al-'Usfuri, Ta'rīkh Khalīfa b. Khayyāt, ed. S. Zakkar (Damascus: Wizārat al-Thaqāfa wa'l-Irshād al-Qawmī, 1967), 2: 748; only the name 'Abdawayh appears. Ahmad b. Yahyā Balādhurī, Kitab Futūh al-buldān, ed. M. J. DeGoeje (Leiden: E. J. Brill, 1866), 296.3-4; again, only the name 'Abdawayh appears, but in this case is encoded as "min wujūh ahl al-dawla."

40. "'Abbāsid Abnā'," 8 n. 68: in Muhammad b. Yūsuf Kindī, The Governors and Judges of Egypt, ed. R. Guest and A. A. al-Askalami (London: Luzac and Co., 1912), 183.7-8, he is noted (in the year 212/827) as al-abnāwi. In the same note Crone considers the case of 'Alī b. Jabala. In reference to this individual, a relative of 'Abd al-Raḥmān b. Jabala, in al-al-Tabarī and al-Balādhurī no nisba is given. However, in the Abū al-Faraj Ișfahānī, al-Aghānī, 24 vols. (Cairo: Dār al-Kutub al-Mișri, 1927-1974), 20: 14, he is described as "min abnä' al-shī'a al-khurāsāniyya min ahl Baghdad." Keep in mind, I am not arguing that the abnä' did not exist or that they were not what they claimed to be.

41. Appears as 'Abdallāh b. al-Jārūd in al-Ya'qūbī, al-Ta'rīkh, 2: 496; also Ibn 'Idharī al-Marrakushī, Histoire de l'Afrique du Nord et de l'Espagne musulmane, ed. E. Levi-Provencal, 2 vols. (Leiden: E. J. Brill, 1948), 1: 86ff.

42. "Aspects of the Transition," 99 n. 47; al-Tabarī, Ta'rikh, 3: 650.

43. al-Tabarī, Ta'rīkh, 3: 650, 798-99, 804; on p. 773 and in al-Ya'qūbī, al-Ta'rikkh, 2: 532, he appears without nisba.

44. al-Ṭabarī $T a^{\prime} r i k h, 3: 826.18-827.1,827.16-17$. There are two accounts of his being dispatched to fight Ṭāhir in al-Tabarī. Also see p. 804. I will discuss this point below.

45. al-Tabarī, Ta'rikk, 3: 826.18-827.1

46. Ibn al-Athīr, al-Kāmil, 5: 146.5-6. He is again identified as al-Anbārī in line 24.

47. M. J. De Goeje, Fragmenta historicum arabicorum, 2 vols. (Leiden: E. J. Brill, 1869), 325.9. Throughout this text Anbār/Anbāri appear where under the old paradigm one expects to find $a b n \bar{a}^{\prime}$. In one instance (p. 321.11) $a b n \vec{a}^{\prime}$ appears, but as $a b n \bar{a}^{\prime}$ al-muluk. 
Given that the Fragmenta is usually quite close to the text of al-Tabarī, the variation is significant. Al-Tabarī's first mention of 'Abd al-Raḥmān being sent out to fight Ṭāhir renders him as al-Anbāri, indicating that his name was in flux and that the assertion under the year $195 / 811$ that he is al-Abnāwi is an ideological identification. ${ }^{48}$ In al-Dinnawari he is also designated $a l-A b n \bar{a} w \bar{i}$ in the same context of his march to meet Țāhir in battle. ${ }^{49}$ The second episode in which he appears as al-Abnāwī in al-Tabarī occurs in the account of his battle with Țāhir, also in 195/811. ${ }^{50}$ The final reference occurs under the year 196/812 when his death is reported to al-Ma'mūn. ${ }^{51}$ Prior to the fourth fitna, before he is dispatched against Tāhir, he is referred to as al-Anbārī. During the fourth fitna when he leads the troops against Țāhir, his name changes to al-Abnāwi. The timing of this shift fits perfectly within my paradigm of the rise of the collective identity during the fourth fitna in response to al-Ma'mūn's threat. Because scholars assume that a person must be $A b n \bar{a} w \bar{l}$, they have ignored the majority of the evidence that renders both 'Abdawayh and 'Abd al-Rahmān as al-Anbārī. Again, if one were going to argue that an orthographic error has occurred, one would have to argue that the occurrences of al-Abnāwi are a mistake.

Now let us turn to the interpretation of terms. Ayalon states: "that a conjunction between two terms does not necessarily imply that the terms are different in meaning, can be learnt from phrases like: Ahl Baghdād wal-Harbiyya; al-Jund min al-Harbiyya wal-Baghdādiyyin .. al-Abn $\vec{a}^{\prime} w a-A h l$ Baghdad . . al-Jund wal-Abn $\vec{a}^{\prime} . "{ }^{52}$ All of these references are found in al-Tabari under the years $196 / 812$ or 201/816, in the throes of the fourth fitna and afterwards. The reference to ahl Baghdād wal-Harbiyya; al-Jund min al-Harbiyya wal-Baghdādiyyin occurs under the year 201/816. However, there is a distinction made between these groups. Further down the page from that reference we read: "The Harbiyya rose against them and expelled them and made Isḥāq b. Mūsā b. al-Mahdī al-Ma'mūn's ruler in Baghdad. Then the people from both sides [of the river] gathered and agreed about this." ${ }^{53} \mathrm{Here}$, the ahl Harbiyya and the ahl Baghdad (indicated as the ahl-jānibayn) are clearly different. The ahl Harbiyya was a subset of the ahl Baghdad. The phrase al-abna ' wa-ahl Baghdad that Ayalon quotes occurs under 196/812. Here too a distinction is made: "He mentioned that the $a b n \bar{a}$ ' and people of Baghdad met him with honor and exaltation. They erected tents for him, and the commanders, chiefs, and nobles went out to meet him." 54 The use of the definite article in "the $a b n \bar{a}$ "' and the lack of it with "people of Baghdad" indicates that $a b n \vec{a}$ ' is also a subset of a larger grouping. The third reference Ayalon uses occurs under the same year. That reference reads, "he dispatched with him a guard from the army and the $a b n \bar{a}$ '." 55 The guard is made up of soldiers from the regular army and from the $a b n \vec{a}$, two different entities.

In much the same vein, Elad argues that

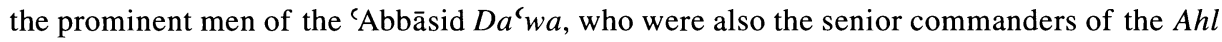
Khurāsān, were called al-Shì' $a$, Shì' at ahl-Khurāsān, or sometimes Shì'at amìr al-Mu'minīn. In later periods their sons and descendants were called (among other epithets) Abna $\bar{a}^{\prime} a l-S h \bar{\imath}^{`} a$. It

48. Cf. al-Tabarī, Ta'rīkh, 3: 804.6 (al-Anbārī); also 3: 826-29 (al-Abnāwī).

49. al-Dīnawarī, Kitāb al-Akhbār, 398.15, 21. Unfortunately, he does not appear earlier in the text for comparison.

50. al-Ṭabarī, Ta'rīkh, 3: 831-33; on 832 he is eulogized as 'Abd al-Raḥmān b. Jabala al-Abnāwĩ.

51. Ibid., 841.8.

52. "Military Reforms," 32. In spite of this assertion, he chooses to read the conjunction "al-abna $\vec{a}^{\prime}$ wa ahl khurāsān" as indicating two distinct groups. See al-Ṭabarī, Ta'rikk, 3: 844.

53. al-Tabarī, Ta'rīkh, 3: 998.20-999.2.

54. al-Tabari, The War between Brothers, trans. M. Fishbein, vol. 31 (Albany: State Univ. of New York Press, 1992), 109 with slight modification; al-Ṭabarī, Ta'rīkh, 3: 846.13-14.

55. al-Ṭabarī, Ta'rīkh, 3: 842.20. 
was customary to add the "nickname" $a l-S h i^{-} a$, to the small number of propagandists for the 'Abbāsid cause in Khurāsān. ${ }^{56}$

He equates these with the ahl Khurāsān and thus with the $a b n \bar{a}$. He cites three instances in al-Ṭabari as his evidence. In two of these, the term "shi' $a$ " indicates "partisans" in reference to the ahl Khurāsān, but its use is generic and is not synonymous with $a b n \bar{a}$ ' $a l$ dawla. ${ }^{57}$ In the third passage, the ahl Khurāsān are clearly denoted as the anșār and the shï' $a$ of the regime: "... ibta'athakum Allāh lanā shī'atan wa-anșāran." 58 As before, the terms are used in a generic sense. This usage does not indicate that everywhere we see "shī' $a$ " or "anșār" we can automatically convert them to mean ahl Khurāsān and therefore abnä' al-dawla ${ }^{59}$ Elad also mentions an incident occurring in 147/764 under the reign of al-Manșūr where someone says, "O Commander of the Faithful, thirty men from the important ones of the Shī'a were brought together from those whom you [had] chosen." ${ }^{\circ} 0$ Taken out of context, this might seem to indicate the $a b n \vec{a}^{\prime}$ al-dawla. However, the comment comes during a dispute over the succession. The text is describing al-Manșūr's appointment of his heir and the various groups that are intriguing to have their candidate selected. ${ }^{61}$ Here "shî' $a$ " indicates the partisans in this struggle. ${ }^{62}$ The assumption is that because the $a b n \vec{a}$ ' existed, then all of these terms must have been used to designate them. This is not the case. They are not equivalent with each other or with $a b n \vec{a}{ }^{\prime}$ al-dawla. They do clearly indicate supporters of various components of the Abbasid regime; that much is not subject to debate. However, "abna $\vec{a}$ al-dawla" has a much more specific usage. If we start with the supposition that the $a b n \vec{a}^{\prime}$ had not formed yet, the multiplicity of terms can be easily explained as indicating a diversity of people.

To elaborate further, one cannot deny that the troops of the early Abbasids are overwhelmingly described as being Khurasanian. However, Elad notes quite correctly that

[t]he term Ahl Khurāsān as a people in general or civilians of Khurāsān is meaningless. Who are these people of Khurāsān? In the period concerned, a political entity did not exist in Khurāsān (and certainly not a national identity). Khurāsān comprised many districts, with diverse and different ethnic groups. Such terms as Ahl al-Shām, Ahl al-'Irāq, Ahl Hims, etc., in the Umayyad and early 'Abbāsid period, refer to Arab regiments recruited from these districts. ${ }^{63}$

This is an important point to keep in mind. This term is a geographic descriptor, in the same way that "Syrian" is for members of the Umayyad forces. The prominence of Khurasanian generals and troops in the first Abbasid caliphs' reigns is to be expected, given that

56. "Aspects of the Transition," 101 n. 54.

57. al-Ṭabarī, Ta'rīkh, 3: 345-46; p. 444.1 which reads “. . . bi ahl khurāsān khayran fa-inna-hum anșāraka wa shī'ataka ..."; another instance on p. 430.15-16 reads "qāla yā ahl khurāsān āntum shī'atana wa anșārana wa ahl dawlatanā ..." In this case the first person plural pronouns should be read in the sense of the royal "we."

58. al-Tabarī, Ta'rīkh, 3: 431.20-432.1.

59. E.g., see al-Ṭabarī, The 'Abbāsid Caliphate in Equilibrium, trans. C. E. Bosworth, vol. 30 (Albany: State Univ. of New York Press, 1989), 46 (170 A.H.), when those who are conspiring against Hārūn al-Rashīd are described as al-Shī ${ }^{-} a$, "the partisans." Bosworth misses the context and reads it as indicating the abnä al-dawla, which, given that context, it clearly is not.

60. Yazīd b. Muhammad al-Azdī, Ta’rīkh al-Mawșil, ed. A. Habibah (Cairo: al-Majlis al-A'lā li’l-Shu'ūn, al-Islāmiyya, 1967), 200.15-16; see Elad, "Aspects of the Transition," 10 n. 54.

61. Following al-Rashīd's succession struggle, the opposition "infiltrates" Hārūn's "shīca." See M. Bonner, "Al-Khalīfa al-Mardịi: The Accession of Hārūn al-Rashīd," JAOS 108 (1988): 87, 89.

62. Anonymous, Akhbar al-dawlah al-'Abbasiyah, ed. 'A. 'A. Duri (Beirut: al-Talia Publishing Co., 1971), 203, 208, 213, 223 is also cited. However, while the term Shī ${ }^{-}$a is used, it is used as indicating partisans of an individual.

63. "Aspects of the Transition," 98 n. 42. 
this was the region in which the revolt began and where the Abbasids recruited much of their army. However, this preponderance of Khurasanians does not allow us to extrapolate that from the outset, or even in the second generation, they automatically formed the collective identity that is represented by the term abna $\vec{a}^{\prime}$ al-dawla. I am not arguing that the ahl Khurāsān and the $a b n \bar{a}^{\prime}$ al-dawla are separate groupings; I am arguing that the $a b n \vec{a}$ ' is a subset of the ahl Khurāsān that forms during the fourth fitna.

Now let us turn to consideration of where and when the word " $a b n \bar{a}$ "" actually appears. The first occurrence of $a b n \bar{a}$ ' in al-Tabarī is "and al-Hazmī al-Sughdī with a thousand $A b n \bar{a}$ ' of the Yaman." ${ }^{64}$ As this describes the descendants of a group of Persians who had immigrated to Yemen before the rise of Islam, it does not refer to the Khurasanian supporters of the Abbasids. Although this is not in dispute, the point here is that "abna")" does not always indicate $a b n \vec{a}$ ' al-dawla, and the definition of a specific usage must be considered in light of the context in which it occurs. For example, an intriguing use of the term that could be construed to indicate abnä' al-dawla is: "and with him was the army of al-Shām, the Jazira and Mosul. The Banū Umayya collected together their $a b n \bar{a}$ ' with him." 65 The "him" in question is Marwān. This form clearly refers to general supporters, those who were tied to the household of the caliph. It does not refer to hereditary proponents or family and certainly does not indicate followers of the Abbasids. ${ }^{66}$ This was an acknowledgement of attachment to the caliph's house, the same claim that was later made during the fourth fitna. Crone says that the first application of the term $a b n \bar{a}^{\prime}$ is "al-Ya'qūbī's statement that 'İsā b. 'Alì $w a-$ man hadara min al-abnā' were reluctant to inform 'Abdāllah b. 'Alī of al-Manșūr's accession (in 136/754)." ${ }^{67}$ She dismisses this as an isolated ascription and most probably anachronistic. It is isolated and possibly anachronistic but it is tempting to view it, as in many of the cases to be discussed below, as having a contextual meaning of "followers" as a generic term and as not specifically referring to the $a b n \vec{a}$ ' al-dawla. Elad argues, "military units bearing this name [abna $\vec{a}^{\prime}$ al-dawla] naturally developed a little later, toward the end of al-Mansuur's reign." ${ }^{68} \mathrm{He}$ cites al-Dīnawarī as evidence for this process. A couple of points must be made. First, the text Elad cites is referring to the reign of al-Rashīd and not that of al-Manșūr. ${ }^{69}$ Second, while it does mention the $a b n \bar{a}$ ' ahl Khurāsān, this, however, does not indicate the abnä' al-dawla. As stated above, the abnä' al-dawla were a subset of the ahl Khurāsān, but this does not mean that the terms express equivalency. Not all the members of the $a h l$ Khurāsān or $a b n \bar{a}^{\prime}$ ahl Khurāsān are identified as abna $\bar{a}^{\prime}$ al-dawla. Only those who had their roots in Baghdad and were present immediately before, during, and after the fourth fitna are referred to as such.

Elad says that the "first reference to military units made of $A b n \vec{a}$ ' is in 178/794-795." 70 He locates this in al-Tabarī, but upon examination nowhere is the term $a b n \bar{a}^{\prime}$ to be found. ${ }^{71}$

64. al-Ṭabarī, The 'Abbāsid Revolution, trans. J. A. Williams, vol. 27 (Albany: State Univ. of New York Press, 1985), 81; al-Tabarī, Ta'rīkh, 2: 1971.

65. al-Tabarī, Ta'rikh, 3: 10.1-2.

66. Lassner, Shaping, 133, has clearly argued, countering Crone, that the term $a b n \vec{a}$ ' does not indicate familial relationships; however, he misses the broader concept that it also does not indicate solely ethnic relationships but indicates a political relationship, based on ties of loyalty and claims to connection with the caliph's household.

67. "'Abbāsid Abnā')" 3.

68. "Aspects of the Transition," 99.

69. al-Dīnawarī, Kitāa al-Akhbār, 390. This page is a discussion of al-Rashīd's succession arrangement for alAmin and al-Ma'mūn.

70. "Aspects of the Transition," 99.

71. al-Tabarī, Ta'rïkh, 3: 630. 
Elad assumes that the reference to 'Abdawayh al-Anbārī is an error and that what is meant is a reference to the $a b n \bar{a}$. . As we have seen, however, it is not a mistake. According to Lassner, the earliest indication of a coherent grouping comes with the statement in al-Tabarì: "[w]hen al-Mahdī sent Hārūn on the summer expedition he sent him on, he ordered that the secretaries of the $a b n \bar{a}^{\prime} a l-d a$ ' $w a h$ should be sent in to him so that he could inspect them and choose one of them for him." 72 But in the next few lines al-Tabari relates: "I examined carefully the sons of my party/partisans $\left(a b n \bar{a}^{\prime}\right.$ shi' $\left.a t i\right)$ and the people of my rule (dawlati)." 73 The personal pronouns are important. These are the sons of his party and his rule that he is choosing from, as opposed to the sons of the party of his father or of his father's rule. These statements are clearly describing individual supporters of the current caliph and do not indicate that the people that he is talking about belong to a coherent group. They are categorizing partisans of al-Mahdi for the purpose of a job search and, as in the earlier case of the supporters of Marwān, the usage of $a b n \bar{a}^{\prime}$ here does not indicate lineal sons but followers.

Crone finds the term cropping up more frequently under the reign of al-Rashīd. "In 189/ 804f the Khurāsānīs asked Hārūn to replace 'Alī b. 'Īsā with anyone from kufātihi waanșārihi wa-abnā' dawlatihi wa quwwādihi." 74 Again, the key to understanding this is to read it more closely, focusing on the possessive pronouns, kufātihi, anșārihi, abnä) aldawlatihi, quwwädihi. They are not requesting someone from the abnä' al-dawla. They are requesting that the Commander of the Faithful send a replacement from "whomever he preferred from (among) his competent officials, his aides, sons/supporters of his rule and his commanders." 75 They are asking for someone, anyone other than 'Alī b. 'İsā from the current command structure in Baghdad, to be sent to govern them.

Turning back to Ayalon, he cites a passage in al-Tabari as evidence for the $a b n \bar{a}^{\prime}$ appearing before the fourth fitna. ${ }^{76}$ However, it says: "CUjayf b. 'Anbasa and al-Ahwas b. Muhājir withdrew [along] with numbers of [the] $a b n \bar{a}^{\prime} a l-\operatorname{sh}^{`} a$ from $\operatorname{Rafi}^{`} \mathrm{~b}$. Layth and went to Harthama." 77 This does not indicate abnä' al-dawla. "Abna ' al-shï' $a$ " indicates "sons of the partisans." The question that should be asked is, partisans of whom? 'Ujayf b. 'Anbasa appears later as a supporter and commander under al-Ma'mūn. ${ }^{78}$ In reference to another example, Ayalon says "it is interesting to note that al-Rawandī's followers were called $A b n \bar{a}$ ' al-dawla, after their leader's book, Kitāb al-Dawla."79 The source for this notion is Ibn alNadīm's Fihrist, which says:

72. Lassner, Shaping, 133. Elad, "Aspects of the Transition," 177, says that the kuttāb abnä' al-da'wa were the propagandists for the revolution. On p. 99, based on this selection, he says that they "constituted something of a sect with a unique status (the most outstanding of whom, were, of course, the Barmakids)." How he extrapolates from this to label them a sect is somewhat baffling.

73. al-Tabarī, Ta'rīkh, 3: 498.5-6; Crone, "The 'Abbāsid Abnā'," 3. Crone notes that the person who was chosen was Yahyā b. Khālid b. Barmak, a descendant of one of the revolutionaries. I do not deny that those who claimed to be $a b n \vec{a}$ ' during the fourth fitna most probably were descended from the "revolutionaries." However, I am arguing that the point at which these individuals began to subscribe to that identity was much later than is assumed.

74. "Abbāsid Abnā)", 4.

75. al-Ṭabarī, $T a ' r i k k h, 3: 703.14-15$.

76. "Military Reforms," 33. Crone also cites this as evidence for them during al-Rashīd's reign, "The 'Abbāsid Abnā'," 4.

77. al-Tabarī, $T a^{\prime} r i ̄ k h, 3: 732.15-16$. An equivalent to this passage appears Ibn al-Athīr, al-Kāmil, 5: 128. There is no mention of "Shī'a" or "abnǟ"."

78. He appears in al-Tabarī, Ta'rïkh, 3: 1093, 1102, 1103, 1105, 1107, 1108, 1109.

79. "Military Reforms," 33. 
and al-Rawandī, who produced the Kitäb al-dawla, used to be his [al-Shaybanī's] neighbor. And the Rawandiyya, the $a b n \bar{a}^{\prime}$ al-dawla, used to gather together to him and he [al-Rawandi] used to go purposefully (on the) day of the majlis of Muhammad and he would sit in the majlis in the mosque and he would read it [Kitäb al-dawla] unto them and when a man from (among) the followers of Muhammad (would) read a thing from his books they shouted at him and they silenced him. 80

Crone calls Ayalon's interpretation of this "mysterious." ${ }^{81}$ At first glance it might seem strange, but Ayalon has clearly considered the context and has read "abnä" here as indicating followers. The Rawandiyya are equated with an $a b n \bar{a}^{\prime}$ al-dawla. They are not the genetic descendants of the supporters of the Abbasids but very specifically the followers of al-Rawandī and his book Kitāb al-Dawla. ${ }^{82}$ Ayalon's interpretation stands.

Seemingly, the first use of the actual phrase abna $\vec{a}^{\prime}$ al-dawla in al-Tabarì is of a man responding to al-Rashĩd's inquiry into his origins, saying: "I stem from the progeny of the "sons of the dynasty'; my family origin is from Marw and my birthplace is the City of Peace." 83 This is Bosworth's translation of this sentence. Now let us look at the Arabic and see what

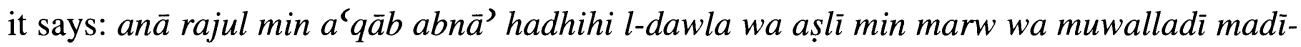
nat al-saläm. This is a much more general statement- "from the sons of this rule," as opposed to sons/supporters of the previous one, with "dawla" referring to al-Rashid's rule. ${ }^{84}$ This is an assertion of individual connection to the household of the caliph, not a claim of membership in an ethnicity or of an institutional grouping. This man identifies himself as a supporter of the dawla, but this is a political assertion of individual connectivity and spatial relationship to a specific ruler, which is then followed by information about where he and his family are from. If this were more than an individual assertion of connection to the household, it would be much more prevalent in the idiom of identification.

Crone notes a particular problem with the sources and how to interpret them:

[t]he sources identify the $A b n \vec{a}^{\prime}$ as the physical descendents of the participants in the revolution, and all the individuals described as $A b n \vec{a}^{\prime}$ actually did or could descend from such participants; they include some Arabs. Yet with the exception of Qahtaba's grandson, the descendents of the most prominent Arab participants are never characterized as $A b n \bar{a}^{\prime}$, and one is specifically excluded from their ranks. ${ }^{85}$

Crone finds a solution for this in the fourth fitna. She argues that most of the revolutionaries were settled in Baghdad at its founding. In turn, their descendants were the ones who fought alongside al-Amīn against al-Ma'mūn and thus the term "came to be synonymous with alAmin's Baghdādi adherents; sons of the revolutionaries who supported al-Ma'mūn ceased to count as Banawis." 86 She thus claims that the term was narrowed, from including all of the ahl Khurāsān to only those who aided al-Amin. She argues that they were not only located in Baghdad and that al-Jāḥiz, Ibn Ṭayfūr, and al-Ya'qūbī were wrong in their assertions

80. Muḥammad b. Isḥāq Ibn al-Nadīm, Kitāb al-Fihrist, ed. G. Flūgel, 2 vols. (Leipzig: F. C. W. Vogel, 1871), 1: $204.3-5$.

81. "Abbāsid Abnā̄", 4 n. 32.

82. Also see al-Tabarī, Ta'rikh, 3: 497.1, “... and indeed we found with him the kitāb al-dawla."

83. al-Tabarī, The 'Abbāsid Caliphate in Equilibrium, 208.

84. al-Ṭabarī, $T a^{\prime} r i k h, 3: 672.6-7$.

85. "Abbāsid Abnā̄," 9.

86. Ibid. 
otherwise. ${ }^{87}$ She cites several examples from different sources for this, which deserve examination before we can continue. She finds evidence in al-Kindī for the $a b n \bar{a}$ ' in Egypt. ${ }^{88}$ However, this reference is not evidence for the $a b n \bar{a}^{\prime}$ living in or being from anywhere other than Baghdad, in fact just the opposite: a contingent of $a b n \bar{a}$ ' is dispatched from Baghdad, indicating that this was where they were located. ${ }^{89}$ However, under closer scrutiny, Hātim b. Harthama b. Acyan was sent to be the governor of Egypt by al-Amin in 194/809-10. Most importantly, he was allotted " 1,000 from the $a b n \bar{a}$.". 90 According to this account, this incident took place before the fourth fitna had started. However, this seems to be an isolated ascription. The term $a b n \vec{a}$ ' does not appear in any form in the entries for governors under either al-Rashīd or al-Ma'mūn's rule. Al-Ya'qūbī provides information that helps to clear up the confusion. He tells us that Hātim b. Harthama b. A'yan was dispatched to govern Egypt after the defeat of 'Alī b. 'Îsā b. Māhān in the year 195/811 and he faced people in Egypt who were calling for changing allegiance to al-Ma'mūn. ${ }^{91}$

Crone cites another snippet from al-Tabari for evidence of the $a b n \bar{a}$ ' in Tarsus. This passage, which occurs upon the death of al-Ma'mūn, is rendered in the translation of Bosworth as "they entrusted the task of watching over him to a guard composed of men from the garrison of $A b n \bar{a}$ ' [Khurasanians] in Tarsus and others . .."92 The Arabic is "thumma wakkalu bi-hi harasan min abna $\bar{a}$ ' ahl tarsüs" meaning "then they assigned for him a guard from among the sons of the people of Tarsus." ${ }^{33}$ This does not indicate abna $\bar{a}^{\prime}$ al-dawla. It is likely that there were people referring to themselves as $a b n \bar{a}^{\prime}$ at this time, but this is not one of those occasions. Crone comments that "not all the Iraqi scholars described as $a b n \vec{a}$ ' $a h l$ Khurāsān necessarily descended from members of the Khurāsānī army." 94 Reading through 166 names under Ibn Sa'd's division for Baghdad yields that neither the nisba abnāwi nor the term banawi appear at all. ${ }^{95}$ The term abnä’ khurasan appears twice; abnä' ahl khurasan appears thirteen times; ahl khurasan appears twice. Where one would expect to find the $a b n \bar{a}^{\prime}$ al-dawla and $a b n \bar{a}^{\prime} a l-d a^{\prime} w a$ in large numbers, there are no references. In fact, there are only seventeen out of 166 references to individuals who could be construed in the old paradigm as $a b n \vec{a}$, which is a strikingly small number. ${ }^{96}$ Importantly, they all died after the fourth fitna. For most of the individuals who could possibly be interpreted as $a b n \bar{a}^{\prime}$ (ten of seventeen) immediately following this identification, their specific geographical origin is given.

One entry in particular deserves closer inspection.

87. Ibid., 9-10: "Ibn Tayfūr also thinks of the $A b n \bar{a}$ ' as the soldiers who opposed al-Ma'mūn (adding that they obeyed him in the end)"; Aḥmad Ibn Abī Ṭāhir Ṭayfūr, Sechster Band des Kitâb Bagdâd, ed. Hans Keller (Leipzig: O. Harrassowitz, 1908), 144: "wa hum qāmū bi-ḥarb amīr al-Mu'minin." There are many references that Crone cites which I have checked, but due to space considerations am unable to expand upon here. However, I have noted a representative sample. This is true for Elad as well.

88. "Abbāsid Abnā'," 4 n. 31.

89. Kindī, Governors and Judges of Egypt, 147.

90. Ibid., 147.6.

91. al-Ya'qūbī, $T a ' r i k h, 2: 533$.

92. al-Ṭabarī, The Reunification of the 'Abbāsid Caliphate, trans. C. E. Bosworth, vol. 32 (Albany: State Univ. of New York Press, 1987), 231.

93. al-Tabarī, Ta'rīkh, 3: 1140.12.

94. "'Abbāsid Abnā)", 3 n. 16.

95. Muhammad Ibn Sacd, Biographien Muhammeds, ed. E. Sachau (Leiden: E. J. Brill, 1904), v. 7, part 2, 66-99. This generation's death dates span the period from 207/822 to 238/852.

96. Admittedly, further research in Ibn $\mathrm{Sa}^{\mathrm{c}} \mathrm{d}$ and other biographical sources is needed for a more representative sample. 
Al-Husayn b. Ibrāhïm b. al-Hurra . . . and he was from the abnä’ ahl Khurāsān from ahl nasā. His father was one of those who left in the call of the Abbasids . . . and al-Husayn was raised in Baghdad. ${ }^{97}$

This entry explicitly describes al-Husayn in terms by which he should be labeled as $a b n \bar{a}^{\prime} a l$ dawla, yet he is not. Why not? Why does he receive the label $a b n \bar{a}^{\prime}$ ahl Khurāsān instead? Did he not support al-Amin? It might be argued that this is a case that shows the terms are equivalent, but consideration in conjunction with the scarcity of usage of the term $a b n \bar{a} \mathbf{b} a l$ dawla in any significant way renders this unlikely. It is important that we consider that even if the sources we have are not representative, at the very least they are diverse enough that if the terms $a b n \bar{a}^{\prime}$ and $a b n \bar{a}^{\prime}$ al-dawla were a common identifier for a socially and politically significant group of elite players with close ties to the caliphs and which formed one of the most significant sources of support for the ruling structure, then our texts would reflect that and the terms $a b n \bar{a}^{\prime}$ or $a b n \vec{a}^{\prime}$ al-dawla signifying this group would show up more regularly. The prominence of usage at a specific point in time (during the fourth fitna) clearly indicates a shift in terminology and meanings.

Crone points out that for al-Jāhiz "it is their residence in the capital and implied political activities there that distinguish them from the Khurāsānīs. ..."98 Thus al-Jāhị viewed the main support both for the Abbasid revolution and for al-Ma'mūn's putsch as coming from Khurasanians, and the term $a b n \bar{a}$ ' was one way to distinguish between the two groups. Crone opines that Ayalon's paradigm holds up well, except that "it merely so happens that the fourth civil war caused the term to shrink ... the term came to be largely synonymous with members of the Harbiyya." 99 Crone's solution can be flipped on its head to provide an equally plausible alternative solution. Her argument rests on the existence of the $a b n \bar{a}$ ' as a wellformed social and political grouping before the fourth fitna. The mechanisms that are at work during the fourth fitna are ignored. Crone assumes that the $a b n \vec{a}^{\prime}$ who fought on the side of al-Ma'mūn would have willingly surrendered their title and status without attempting to counter this. ${ }^{100}$ In this paradigm the groups are renamed without impact and without consideration of what that renaming carries with it. Crone observes, "the descendants of Mu'ādh b. Muslim, a client of B. Dhuhl who was one of the ahl al-dawla, likewise had ties of fosterage with the caliphs, though they are never explicitly characterized as $A b n \bar{a}^{\prime} . "{ }^{101}$ She is using this to contrast with Yahyā b. Khālid b. Barmak who was an "Iranian" and "the very first individual to be singled out as" $a b n \vec{a}$. ${ }^{102}$ As her evidence for this, she cites that he was the man chosen by al-Mahdī to go with al-Rashìd on the summer expedition. Again I point to this text with the reminder that Yahyā is noted as a member of abna $\bar{a}^{\prime} \operatorname{sh}^{\prime}$ 'ati and the ahl dawlati. ${ }^{103} \mathrm{He}$ is one of the partisans of al-Mahdi and one of the people of his rule, in a situation that is charged with a fractious struggle over the succession. These ascriptions do not indicate membership in a broader grouping.

97. Ibn Sacd, Biographien Muhammeds, v. 7, part 2, 87.

98. "“Abbāsid Abnā)," 9; also noted by Lassner, Shaping, 132.

99. "'Abbāsid Abnā̄," 10, citing Ayalon, "Military Reforms," 7ff., 11, and Lassner, Shaping, 134.

100. Seemingly, this also implies that al-Ma'mūn's army was made up of Arabs, because as Crone puts it, the Arabs already "had a prestigious identity" and had no need to assert their status as participants in the revolution. "'Abbāsid Abnā̄", 10-11, 9: "The descendants of the best known ahl al-dawla mostly did support al-Ma'mūn ... so the only offspring of a famed participant in the revolution to be explicitly linked with the $A b n \bar{a}$ ' is 'Abdāllah b. Humayd b. Qahțaba ..." who fought for al-Amin.

101. "Abbāsid Abnā̄," 7.

102. Ibid.

103. al-Tabarī, Ta'rikh, 3: 498.6. 
Crone cites Ibn Tayfūr's Kitāb Baghdad as saying that "their fathers are the ones who conducted the revolution." ${ }^{104}$ The text clearly says: wa-abä'uhum hum alladhina qādu aldawla/ and their fathers were the leaders of the dawla. ${ }^{105}$ Again, the claim that they were descendants of the original revolutionaries is not in dispute. In fact, it was precisely this element that gave their claim legitimacy. It is the timing of when and who began to assert the claim that is significant. Ibn Tayfür also relates in the same line that the $a b n \vec{a}$ ' were the ones who rose up and fought against al-Ma'mūn in the fourth fitna. ${ }^{106} \mathrm{He}$ makes it explicitly clear who the $a b n \bar{a}$ ' are: they are the sons of the original supporters in Baghdad who fought against al-Ma'mūn. Crone seeks to account for the statements of al-Jāhiz, al-Ya'qūbì, and Ibn Tayfür that the $a b n \bar{a}$ ' were Baghdadi, by stating that in the Harbiyya quarter " $[\mathrm{m}]$ ost of them must have been ethnic Iranians. Because these people predominated in al-Amin's army and the subsequent opposition to al-Ma'mūn, they so-to-speak hijacked the term $a b n \bar{a}^{\prime} a l$ dawla, and so a Banawi in the sources is almost always a non-Arab." ${ }^{107}$ This and the argument that the siege caused the term abna $\bar{a}^{\prime}$ al-dawla to narrow make sense, if we accept that the $a b n \bar{a}^{\prime}$ al-dawla as a category and identity existed long before the fourth fitna and that those residing outside of Baghdad relinquished the title and status without a murmur.

But if this assumption is set aside, we can process all of this information in an alternative way. Crone is partially correct when she makes the observation that "it was their political role which singled them out from everybody else. Collectively, they were abna $\bar{a}^{\prime} k h u r a \bar{s} a \bar{n}$ almuwalladīn, people of Khurāsānī descent born 'here', i.e. in the capital, not ordinary Khurāsānīs, let alone ordinary Arabs or Iranians devoid of special ties with the 'Abbāsid house." 108 I suggest that the Baghdadi descendants of the revolutionaries who supported al-Amin defined themselves during the fourth fitna as the $a b n \bar{a}^{\prime}$ al-dawla in an effort to stake their claim to membership in the household and the immutability of their position in defense against the coming onslaught of al-Ma'mūn's followers, thus making their claim against those who might take their place. ${ }^{109}$ It is interesting to note that during the siege of Baghdad there was considerable fluidity, with offers of increased payments triggering defections from both sides. ${ }^{110}$ We see people who would otherwise have been labeled as $a b n \vec{a}$ ' joining up with Tâhir due to anger at al-Amin's overtures. Crone makes a key observation but chooses to ignore it: "The $A b n \bar{a}$ ' regarded the 'Abbāsid caliphate as a bulwark against such people, who might otherwise absorb them ..."111 It was this threat that drove them to find their collective identity and also drove them to collective action. Baghdad and the fourth fitna was where and when they formed, and they were thus defined by this context. Using this as our basic assumption, the assertions of al-Jāhịiz, Ibn Ṭayfūr, and al-Ya'qūbī make perfect sense.

Terminology shifts have meaning and indicate stress on a social system. The $a b n \bar{a}>a l$ dawla changed their identification from ahl Khurāsān, etc., in opposition to al-Ma'mūn's

104. "'Abbāsid Abnā)," 3.

105. Ibn Abī Țāhir Ṭayfūr, Sechster Band des Kitâb Bagdâd, 143-44.

106. Ibid., 144.1: wa hum qāmū bi-harb amï al-mu'minin.

107. "Abbāsid Abnā'," 10.

108. "'Abbāsid Abnā'," 13. M. S. Gordon posits an interesting interpretation of the term muwalladūn, "this is probably used by al-Ya'qūbī to refer to the Iraqi civilian population" ("The Breaking of a Thousand Swords: A History of the Turkish Community of Samarra [218-264 A.H./833-877 C.E.]" [Ph.D. diss., Columbia University, 1993], 320).

109. Lassner, Shaping, 134-35, notes that "Baghdadis no doubt suspected that a victory for the pretender would enhance the position of the new Khurāsānī forces ..."

110. Kennedy, Armies of the Caliphs, 79-80.

111. "'Abbāsid Abnā̄"," 14. The bulwark was against "Ṭāhir's 'ajam [who] were raw Iranians, people who had failed to transcend their local origins by participation in the high culture." 
men. They were staking a specific claim to a place in society, in response to a threat to that place. The collective " $a b n \bar{a}$ "” came together as $a b n \bar{a}$ ' at this point and not before. It is not necessary to go through all that Crone and others have gone through to explain why the $a b n \bar{a}^{\prime}$ show up so clearly during the fourth fitna and not before and really not much afterwards. Occam's razor applies. Before, the term ahl Khurāsān had been a more inclusive one. For the elite of Baghdad, in the face of the opposition of al-Ma'mūn, it was prudent, expedient, and necessary to narrow the categories of belonging to exclude his followers. What we see is not just a narrowing in terminology but a paradigm shift. The definitions and terminology are changed to reflect a realignment of forces and groupings. The abna $\bar{a}^{\prime}$ al-dawla staked a claim to status as members of the household as original supporters of the regime, but they had to do so in a way that excluded al-Ma'mūn's forces while differentiating themselves from the rabble of Baghdad (the "naked warriors") that al-Amin was arming. In Egypt the call to switch allegiance to al-Ma'mūn is addressed to the ahl Khurāsān and not to the $a b n \bar{a}$ ' $a l$ dawla. ${ }^{112}$ The abna ' could not use the regional identity of "Khurasaniness" as ahl Khur$\bar{a} \bar{s} \bar{n}$ or solely descent from an original supporter; but these, combined with the locality of Baghdad, offered a convenient limiter. Thus they are Khurasanian but different from alMa'mūn's Khurasanians, descendants of the original supporters but different from those

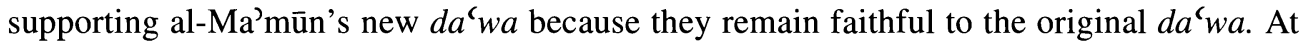
the same time, their ties to the dynasty ran deep, unlike the rabble of Baghdad who rose to support al-Amin.

In the ninth century, people, especially the so-called $a b n \bar{a}^{\prime}$, defined their public identity in relation to the "state" (meaning the ruling body) and their fellow members of society and these ascriptions tied them and society together. When the state, in the form of the caliph, was replaced, these identifications had to be renegotiated. In the case of the $a b n \bar{a}^{\prime}$, the identity formed in response to the threat from the "usurper," al-Ma'mūn. They called themselves the $a b n \bar{a}^{\prime}$ al-dawla as a means of asserting their claim to legitimacy and their attachment to this caliph (al-Amin) in contrast to a competing claim to elite status. I do not deny the existence of ethnic or cultural differences. The question that must be asked is when and if these are relevant to the motivations and activities of people. The determining variables for the $a b n \bar{a}^{\prime}$ collective identity were physical location in Baghdad and specific ties to the caliph. When they are designated as the $a b n \bar{a}$, they are clearly and exclusively inhabitants of Baghdad. ${ }^{113}$ The claim posits position and opposition. In essence: "We are the abnä' al-dawla, the sons of the regime, the legitimate heirs to the original supporters of the regime." 114 "As a result of this, we are entitled to our privileged access to the bounty of the regime." "We are not the rabble (the naked warriors) nor are we the newcomers/faithless-ones (sc. Tāhir, Harthama b. Acyan, and their forces)." 115 The logic appears to be that if "we" are the physical members of the house, then "we" cannot be removed from "our" positions.

112. Kindī, Governors and Judges of Egypt, 148.10: wa danā ilā ahl khurāsān fì khala'i Muhammad wa'l-'aqd lil-Ma'mūn.

113. Ayalon, "Military Reforms," 6-7, citing al-Jāḥiz, "Manaqib al-Atrak," 15.2, 6 and Ibn Abī Ṭāhir Ṭayfūr, Sechster Band des Kitâb Bagdâd, 143-44.

114. E.g., see al-Ya'qūbī, al-Ta'rīkh, 2: 547.4-5, in the year 201/816-17: "we are the helpers of your regime and indeed we fear that you will take [rule] this state/regime by what [is] related in it from the directions/guide of the Zoroastrians."

115. See al-Tabarī, Ta'rīkh, 3: 792.18-793.3: "And he said, so what is your opinion about the armies of 'Abdallah? He replied, 'they are a people [who are] on the way of their cause because of the length of their effort and what they are in agreement about their concern.' And what of their generality [commoners]? He replied, 'they are a people who were in great tribulation as a result of the injustice done unto them. And because they, through him, have 
Under the year 195/811, in the account of the battle between Țāhir and 'Abd al-Rahmān, we read: "'Abd al-Rahmān was repeatedly saying to his companions, 'Oh Abnā'! Oh sons of kings, and [those] familiar with swords! Verily they are the 'ajam and are neither the same as people of endurance nor steadfastness." "116 It is a claim to historical connectedness in "vertical time." 117 The term 'ajam does not of necessity indicate "Persian," but it does refer, in a pejorative manner, to a newcomer to the community, thus impugning the status of the warriors under Tâhir's command. ${ }^{118}$ This is an assertion of the pre-existence of a status, not unlike the claims made by nationalists for the historical connectedness of their people. Declarations of this nature tend to have some element of truth; those who were claiming this status were the descendants of the Abbasid revolutionaries. However, it should be pointed out that Tāhir's father was a Khurasanian commander and his grandfather fought on the side of Abu Muslim in the original revolt, yet he is not identified as one of the $a b n \bar{a}^{\prime}{ }^{119}$ In spite of what should have been a common bond, origin from Khurasan, the approach of al-Ma'mūn's forces signaled the threat of the beginning of a new regime. These individuals chose the identity of the $a b n \bar{a}^{\prime}$ al-dawla, because it was a claim that they could sustain of physical attachment to the dynasty and to the caliph. Al-Jāhiz quotes one of the $a b n \bar{a}$ : " [w]e were brought up by the caliphs and we are the neighbors of viziers. We were born in the courts of our kings and under the wings of our caliphs. We adopted their manners and followed their example. We know nobody else but them and we are known only as their(s) and nobody else's." 120 Here is an explicit claim by an individual, through the medium of al-Jāhiz, for inclusion in the entourage of the caliph, stating clearly who and what he and they were. It was an assertion that they occupied a place of power and privilege, of which they could not be dispossessed (even though they eventually were).

Al-Ma'mūn's new $d a^{\text {' } w a ~ s p e l l e d ~ o n e ~ t h i n g ~ f o r ~ t h e ~ e x i s t i n g ~ p o w e r ~ s t r u c t u r e, ~ a ~ n e w ~ d a w l a . ~}$ Al-Ma'mūn's followers would expect to be rewarded and the elite in Baghdad knew how. In this new paradigm the "abnä' al-dawla" would be superfluous. Also, as with any successful revolution or upheaval of this sort, in the first period the supporters of the old regime bear the brunt of retribution and dispossession until the dust settles. It is only then that the new regime recognizes that it needs the expertise and cooperation of the former members of the old regime. This can explain the process by which the $a b n \vec{a}$ ' were brought back into the fold. Once he came to Baghdad in 204/819, al-Ma'mūn recognized that he needed help in ruling

come to what they desire of their property and of the comforts of life, they defend prosperity new to them and they remember tribulation [and] they do not wish to return to it."

116. Ibid., 3: 829.3-5.

117. Anderson, Imagined Communities, 26.

118. Edward William Lane, Arabic-English Lexicon (Cambridge: Islamic Texts Society, 1984), 2: 1967. It indicates "[Foreigners, as meaning] others than Arabs; .. . [often used as implying disparagement, like barbarians; and often especially meaning Persians; ] . . a man not of the Arabs." It does not necessarily mean "Persian," much less "Iranian." The root meaning has to do with speaking unclearly or poorly, signifying an outlander usually from the east; see Gordon, "The Breaking of a Thousand Swords," 49 n. 139, for other references. Also see C. Robinson, "The Study of Islamic Historiography: A Progress Report," Journal of the Royal Asiatic Society 7 (1997): 220.

119. See al-Tabarī, 'Abbāsid Authority Affirmed, trans. J. D. McAuliffe, vol. 28 (Albany: State Univ. of New York Press, 1995), 235 n. 1088.

120. Ayalon, "Military Reforms," 7. Also cited in Crone, "'Abbāsid Abnā'," 16, who says, contrary to Zakeri, that "they are not boasting of the past relationship with the Sasanid emperors, but of their current relationship with the "Abbasid caliphs: kings is simply a synonym for caliphs here." This hits the nail on the head, but Crone does not recognize it for what it is. Citing al-Jāḥiz, "Manāqib al-turk" in Rasā'il al-Jāḥiz, ed. 'A. S. M. Hārūn (Cairo, 1965), 28. 
and keeping order in the city. As a result, he made a concerted effort to make peace with them.

At the beginning of the siege in 197/812, al-Ma'mūn's army was sitting at the gates of Baghdad after having won several victories en route. Most importantly, this force was made up of rivals for the positions of the Baghdad elite. The individuals who were to make up the $a b n \bar{a}$ ' faced a "legitimation crisis." 121 This legitimation crisis forced a coalescing of groups around identities that provided meaningful responses to the situation and that served to protect status and position, meaning that those who held position and power saw advantage in coalescing for collective action. ${ }^{122}$ In the terminology of Charles Tilly, the claim of alMa'mūn and his followers or supporters forced "reactive collective action" on the part of the notables of Baghdad. ${ }^{123}$

In addition, during the siege those without position and power, i.e., the "Naked Warriors" saw a way to assert their belonging to the community and their status as defenders of the faith. ${ }^{124}$ They were acting with "proactive collective action." 125 This deepened the legitimation crisis, enhancing the need to identify collectively for the elite elements of Baghdad. This does not need to have been a conscious choice, as people are rarely so baldly opportunistic. ${ }^{126}$ There is no single catalyst for the concrescence of any identity, but for the $a b n \bar{a}$ ' the army bearing down on them and the siege of Baghdad were the main impetus for mapping a new one. This pressure, combined with the arming of the naked warriors, meant that in order to survive and have hope of maintaining their social roles, even if defeated, they would have to tie themselves to the household and not just to the caliph. This meant that they would have to stake claim to this position and define themselves as different from the other groups with whom they were jockeying. ${ }^{127}$ With regard to modern national identities, Rodney Hall tells us:

individuals perceive that their interest lies squarely in the defense and promotion of this collective identity. The fundamental, even primordial, motive (or "interest") of self-preservation will

121. J. Habermas, Legitimation Crisis, trans. T. McCarthy (Boston: Beacon Press, 1975), 3-4. In periods of crisis members of society restructure their interpretive system, which had allowed them to identify "one another as belonging to the same group, and through this group identity assert their own self-identity." In this process of restructuring, the individuals seek out new ways of asserting belonging.

122. A. Merlucci, "The Process of Collective Identity," in Social Movements and Culture, ed. H. Johnston and B. Klandermans (Minneapolis: Univ. of Minnesota, 1995), 48.

123. Tilly, "Revolutions and Collective Violence," in Macropolitical Theory, ed. F. I. Greenstein and N. W. Polsby (Reading: Addison-Wesley, 1975), 507: "reactive collective action: some group or its agent lays claim to a resource currently under the control of another particular group, and the members of the second resist the exercise of that claim." And "I suggest that contenders which are losing membership in a polity are especially prone to reactive collective action."

124. See Bonner, "Definitions of Poverty," 343-44.

125. Tilly, "Revolutions and Collective Violence," 507: "proactive collective action: some group carries out an action which, under the prevailing rules, lays claim to a resource not previously accorded to that group; at least one group intervenes in the action and resists the claim."

126. L. Greenfeld, Nationalism: Five Roads to Modernity (Cambridge, Mass.: Harvard Univ. Press, 1992), 178. Greenfeld makes the observation that "the adoption of a new, national identity is precipitated by a regrouping within or change in the position of influential social groups-a crisis of identity, structurally expressed as 'anomie' - which creates among them an incentive to search for and, given the availability, adopt a new identity. The crisis of identity as such does not explain why the identity which is adopted is national, but only why there is a predisposition to opt for some new identity." I would add that it is not essential that they choose a national identity, any identity that provided salient meaning and support would do.

127. See H. Johnston and B. Klandermans, "The Cultural Analysis of Social Movements," in Social Movements and Culture, 10. 
then ensure that individuals will come fully to the defense of the collective identity that they see as fully constitutive of their selves when they feel that collective identity is threatened. ${ }^{128}$

People are multifaceted. The collective identity does not have to be the sole form of identification for the threat to cause baseline tremors in the individual's perception of his or her social reality. I disagree with the notion that it is a purely modern state of affairs that people subscribe, unsubscribe, and resubscribe to group identity based on relationships and changing conditions. How a person self-identifies is determined by the question to which he is responding. A person may answer in one context with a tribal name and in another with a geographical descriptor. We all have fragments of identity that we deploy in response to different situations. ${ }^{129}$ All around us (metaphorically) are artifacts or tools of identity that we pick up when they are relevant and useful, and discard when they are not meaningful. This does not mean that identities are not strongly held or that they are created out of nothing for purely utilitarian reasons. It means that they are determined by the milieu in which a person is located and how that individual interprets and responds to that context. This is what those who claimed to be the $a b n \vec{a}^{\prime}$ al-dawla, the sons of the dynasty, were doing. They were picking up an identity-tool, using it and when it was no longer meaningful they put it back down.

This nomenclature is not determined by some sort of cynical, manipulative conspiracy directed from a central core for its own gain, as Ernest Gellner, Benedict Anderson and E. J. Hobsbawm might be interpreted as saying. ${ }^{130}$ Clearly identities can be and are used and strengthened by political leaders for cynical and manipulative purposes, but it does not necessarily follow that those forces manufacture the building blocks for them. ${ }^{131}$ David McCrone makes the point that nationalisms, and I would add all identities, are defined and determined by individuals making conscious or unconscious choices. ${ }^{132}$ These choices can be and are reinforced by a government using the tools that Anderson describes: maps, a pledge of allegiance, a flag, and language. ${ }^{133}$ However, at root, their basic strength comes from personal subscriptions. Everyone is distinct and different and knows what he identifies himself as. The trick comes in making the borders of that identity just blurry enough so that he finds a connection with others close enough that they can claim the same identifier and thus a commonality allowing for the perception of shared interests. The blurring can come from above, using the processes that Anderson describes but, most importantly, it comes from within because it serves some specific need or interest. This does not have to be, nor is it likely to be, conscious. The members of a social system make interpretations of their surroundings and of those surrounding them that allow them to be and to accept others as belonging to the same group, which in turn allows each person to proclaim an identity. ${ }^{134}$ It

128. R. B. Hall, National Collective Identity (New York: Columbia Univ. Press, 1999), 38.

129. See R. Tapper, "Ethnic Identities and Social Categories in Iran and Afghanistan," in History and Ethnicity, ed. E. Tonkin (London: Routledge, 1989), 239: "Cultural identities, whether ethnic or otherwise, make sense only in social contexts, and they are essentially negotiable and subject to strategic manipulations. Individuals claim status, present themselves, in different ways in different contexts. How they do so depends particularly on power relations, government policies, and local hierarchies."

130. E. Gellner, Nations and Nationalism (Oxford: Blackwell, 1983); idem, Nationalism (London: Weidenfeld \& Nicolson, 1997); Anderson, Imagined Communities; Hobsbawm, Nations and Nationalism Since 1780, 2nd ed. (Cambridge: Cambridge Univ. Press, 1992).

131. For a little acknowledged subtlety in Gellner's writings, see his Thought and Change (London: Weidenfeld and Nicolson, 1964), 169. In the same breath as his statement that nationalism "invents nations where they do not exist" he notes that cultural raw materials must be available for this invention.

132. McCrone, The Sociology of Nationalism, 25-36.

133. Anderson, Imagined Communities, 113-14.

134. See Habermas, Legitimation Crisis, 3-5, for the seeds of the following line of thought. 
is through this process that a collective identity is defined and ultimately subscribed to. If the social system that is partially founded upon this collective identity is threatened, this presents a very real threat to the individual's sense of self. If a rupture in the system occurs, one is forced to reassess his place in relation to other members of a collective identity to which they jointly subscribe and the relation of this collective identity to the social system at large. If the rupture is severe enough, the social system begins to break down and members are forced to re-identify in order to find their place within that system. If the collective identity's relevancy or meaning is undermined, people will search for alternative definitions for it; if none can be found, they will search out other forms with which to encode their selves and their social space.

This, I suggest, is what occurred with the $a b n \bar{a}^{\prime}$ al-dawla. They responded to the threat of al-Ma'mūn and his followers. Many of the elite in Baghdad found interests that they had in common and coalesced into a collective. Part of this involved defining their relationships to the caliph, to the rabble of the capital, to al-Ma'mūn's forces, and to each other. As long as their prosperity and position was tied to the caliphate and there was a clear and present threat to their positions, then there was reason and reward in acclaiming themselves the $a b n \bar{a}^{\prime} a l$ dawla tied to al-Amin, but most importantly to the dynasty. Hence they chose the phrase $a b n \bar{a}^{\prime}$ al-dawla and not $a b n \bar{a}^{\prime}$ al-Amin. Once al-Amin had been removed from power, the collective identity of the $a b n \tilde{a}^{\prime}$ al-dawla had to be redefined or it would pass from usefulness. Each had to acculturate to the new regime and newly redefined roles, which some of them did and were reintegrated. However, they were no longer at the center of power and the designation as members of the abna $\mathbf{3}$ al-dawla no longer held compelling utility. It disintegrated and in its place a host of subsumed identities resurfaced and other choices presented themselves. The individuals discarded the no longer relevant identifier and turned to other alternatives. It would occasionally be used again, but it never held the force or urgency that it had during the fourth fitna.

Being $a b n \bar{a}$ ' al-dawla was not an essentialized part of their selves, nor had there been time for it to become perceived as such. They could choose to use different terminologies. It was only in the face of al-Ma'mūn's forces, which expressly intended to replace them at the center of the Islamic world, that some of the descendants of the Abbasid revolutionaries began to define themselves as the sons of the dynasty, and in the process excluded al-Ma'mūn's followers from the category. Once the threat had been fulfilled, new identities were necessary and old ones that had been subsumed were allowed to resurface. The collectivity, made up of individuals who had come together to form the $a b n \bar{a}^{\prime}$ al-dawla, splintered into its constituent parts based on preexisting, underlying knowledges of self. What had become the second tier of identification rose again to the forefront and returned to being primary motivators for collective action, based on different criteria. The $a b n \vec{a}$ ' al-dawla supra-identity had been asserted to fulfill a specific defensive need. This is not to say that it was false, but that it was "imagined" and the materials that were available were used once they became relevant and useful. Before, they had not been relevant, nor were they afterwards.

\section{THE FOURTH FITNA AND THE POINT OF DEFINITION}

Now let us turn to the formation of this collective. Upon al-Rashīd's death, al-Amin became caliph and al-Ma'mūn governed in Khurasan. ${ }^{135}$ Several attempts were made to

135. The difficulties surrounding the succession agreement will be ignored here. For further information, see $\rightarrow$ T. El-Hibri, "Hārūn al-Rashīd and the Mecca Protocol of 802," International Journal of Middle East Studies 24 (1992). 
convince al-Ma'mūn to step aside in Khurasan and become a less powerful governor, but he refused. A tense, nervous coexistence followed for almost two years. Matters became more heated in Safar 195/November 810 when al-Amin designated his son as the heir and removed al-Ma'mūn from the succession. In response, al-Ma'mūn proclaimed himself "imām al-hudā," the "imam of Right Guidance," drawing an obvious contrast between himself and his brother. ${ }^{136}$ Then al-Amin sent a letter to his commanders in which he listed what alMa'mūn had done wrong. ${ }^{137}$ The letter made it clear that al-Ma'mūn was asserting that in essence he was caliph. Al-Amin pointed out that this represented a threat to those commanders whom he had just reminded of their oaths and ties of loyalty to him. Al-Fadil b. Rabi ${ }^{\mathrm{c}}$ "mentioned concerning it that no one had a right to the imamate or the caliphate except the Commander of the Faithful, Muhammad al-Amīn, and verily God did not give to 'Abdallāh or any other a share of these or [even a] portion." ${ }^{138}$ Al-Amin then dispatched his army under the command of 'Alī b. 'Īsā b. Māhān. Al-Ma'mūn responded, after protracted waffling, by unleashing Tāair b. al-Husayn to fight them. In what might be a trope, Tāhir's army is described as being vastly outnumbered. ${ }^{139}$ Despite this, he defeated his opponent at Rayy in Sha'bān 195/April-May 811. As a result, al-Ma'mūn officially took the title of caliph. Kennedy calls this "an unqualified disaster" for the $A b n \bar{a}$ ' and that "from this point they were struggling for survival." ${ }^{40}$ It was an unqualified disaster, but not for a group called the $A b n \vec{a}^{\prime}$.

There are two accounts of this battle in al-Tabarī, but with differing dates. Both of these deserve close inspection to determine who took part on al-Amin's side and how their identities were encoded. In the first account al-Amīn sends 'Alī b. 'Īsā with a large army forcibly to bring al-Ma'mūn to Baghdad, in silver chains if need be. ${ }^{141}$ 'Ali leaves Baghdad in the middle of Jumādā II, 195/March, 811.142 The armies of Ṭāhir and 'Alī b. 'Īsā meet outside of Rayy in Sha'bān, 195/April-May, 811. Paralleling the battle of Șiffīn, a truce is called and some of Tāhir's men remind 'Alī b. 'Īsā of his oath of allegiance to al-Rashid and the succession agreement. 'Ali responds in anger at the messenger whom he recognizes, saying "Oh ahl Khurāsān, for he who brings him to me there will be a thousand dirhams!" $143 \mathrm{He}$ calls his troops the Ahl Khurāsān. He does not refer to them as abnä' or abnä' al-dawla. In a similar way, 'Alī is characterized as "the shaykh of the $d a^{\text {' }} w a$ and the remainder (baqiya) of the people of its partisans," 144 and al-Amin says that "the shaykh of this $d a^{\text {' }} w a$, and the tooth $(n \bar{a} b)$ of this dawla" will not abandon his imam. ${ }^{145}$ In this account of the battle "Ali b. 'İsā is summarily killed and a dispute ensues over credit for killing him. ${ }^{146}$

136. al-Tabarī, Ta'rīkh, 3: 796.6 .

137. Ibid., 796.

138. Ibid., 797.4-6. His and al-Amīn's letter stop just short of labeling al-Ma'mūn an unbeliever. It is important to note that these commanders are identified as ahl Khurāsān and not as abnä' al-dawla.

139. Kennedy, The Armies of the Caliphs, xiii, 50.

140. H. Kennedy, The Prophet and the Age of the Caliphates (New York: Longman, 1986), 150.

141. al-Ṭabarī, $T a^{\prime} r i ̄ k h, 3: 798.1$. It is interesting that al-Ya'qūbī, $a l-T a^{\prime} r i k k h$, v. 2, 530.13 characterizes this force as mercenary.

142. al-Ṭabarī, Ta'rïkh, 3: 797.18-19.

143. Ibid., 801.3-4. In al-Ya'qūbī, al-Ta'rìkh, v. 2, 532.6-7, they are also referred to as the ahl Khurāsān.

144. al-Tabarī, Ta'rīkh, 3: 808.16. In al-Dīnawarī, Kitāb al-Akhbār, 396.7, al-Amīn calls him "the Shaykh of this dawla."

145. al-Tabarī, Ta'rỉkh, 3: 810.1-2.

146. Ibid., 801-2. 
In the second account, the date for 'Alī b. 'İsā's departure from Baghdad is given as the 7th of Sha'bān 195/May 4, 811. ${ }^{147}$ Al-Amīn "called 'Alī b. 'Īsā b. Māhān and he assigned to him 50,000 horsemen and infantry from among the ahl Baghdad." ${ }^{148}$ The abnä' al-dawla are not summoned, only the ahl Baghdad are named. It is at this point that the oath is taken to the new heirs. In return, al-Amīn "gave them, the Banū Hāshim and the commanders and the army, things and rewards"-again no $a b n \vec{a} .{ }^{149}$ As in the first account, the two armies meet outside of Rayy. The battle is fierce, but eventually Taahhir's forces begin to carry the day and 'Alī b. 'İsā's troops begin to retreat. As the rout is on, 'Alī b. 'İsā calls out: "Where are the companions of the bracelets and the crowns? Oh, ye $a b n \bar{a}$, to the counterattack!" 150 $\mathrm{He}$ is killed after uttering these words. Interestingly, he said $a b n \vec{a}^{\prime}$ and does not say $a b n \bar{a}^{\prime}$ al-dawla. In this entire encounter, in both accounts, this is the only reference to $a b n \bar{a}$.

In the account of al-Dīnawarī, al-Amīn sends 'Alī b. 'İsā out with six thousand men "from the champions of the army [infantry] and their horsemen," and his army is described as "ahl Khurāsān." "151 At one point in al-Dīnawarī, before 'Alī b. 'Īsā is sent out, the comment is made: "Oh, ahl Khurāsān, renew your oath to your imam al-Amīn." 152 The supporters of al-Amīn are labeled ahl Khurāsān. Nowhere in al-Dinnawarī's account of the battle is there a reference to $a b n \bar{a}$ ' of any sort. ${ }^{153}$ But when al-Amin is told about the defeat, 'Abd alRahmān is labeled as $a l-A b n \bar{a} w \bar{l}$ and is dispatched with men from the $a b n \bar{a}{ }^{\prime}{ }^{154}$

In al-Tabarī, as in al-Dīnawarī, the next group that is sent out against Ṭâhir is clearly labeled as $a b n \bar{a}$ '. When the news of 'Alī b. 'İsā's defeat and death reaches Baghdad, "the people spread false rumors ... and this was Thursday, the middle of Shawwāl of the year 195 (July, 811)." 155 Five months after 'Alī b. 'İsā's force had been dispatched, another is sent out against Țāhir by al-Amīn. This one is led by 'Abd al-Raḥmān b. Jabala. Al-Ṭabarī informs us that al-Amīn "sent 'Abd al-Raḥmān al-Abnāwì among 20,000 men from the $A b n \bar{a}$ " " and "horsemen of the $A b n \bar{a}$ ' and people of bravery, courage, and ability from among them." 156 This time the army is clearly labeled not as ahl Khurāsān, as 'Alī b. 'İsā's army had been, but as $a b n \bar{a}$. This is the point at which the $a b n \bar{a}^{\prime}$ appear, ${ }^{157}$ following the defeat of al-Amin's best general and with the realization that al-Ma'mūn and his forces present a very real threat. ${ }^{158}$ Interestingly, one of al-Amīn's commanders says of T⿳āhir: "And with

147. Ibid., 818.12-13. Only the year is given in al-Ya'qūbì, al-Ta'rikh, v. 2, 532.

148. al-Tabarī, Ta'rīkh, 3: 817.13-14.

149. Ibid., 818.11. The march east is paralleled in al-Dīnawarī, Kitāb al-akhbār, 396-98; Ali b. al-Husayn Mas' 'ūdī, Les praires d'or, ed. C. B. de Meynard (Paris: Imprimerie nationale, 1928), v. 6, 420-24; Ibn al-Athīr, al-Kämil, v. 6, 166-67.

150. al-Tabarī, Ta'rīkh, 3: 824.14-15.

151. al-Dīnawarī, Kitāb al-Akhbār, 396.11-12, 14.

152. Ibid., 393.5

153. Ibid., 396-98.

154. Ibid., 398.15 See above-the reader will remember him from the discussion of the controversy over whether he is anbāri or $a b n \bar{a} w \bar{i}$. This is when his name changes.

155. al-Tabarī, Ta'rīkh, 3: 825.19-21. This passage is paralleled in Ibn al-Athīr, al-Kāmil, v. 6, 170; De Goeje, Fragmenta, 325.

156. al-Ṭabarī, Ta'rīkh, 3: 826.18-827.1, 827.3-4.

157. al-Ya'qūbī, al-Ta'rīkh, v. 2, 532.7. Al-Amīn's army is encoded as ahl Khurāsān but on p. 533.2 his supporters are the "ahl harbiyya wa'l-abnä'."

158. Ibid., 530-33. The sequence of events is: al-Ma'mūn's forces gain control over almost everything but Baghdad, then 'Abd al-Raḥmān is sent out to face Țāhir. 'Abd al-Raḥmān is defeated, and then we are told "fa-jama'a ilayhi ahl harbiyya wa'l-abnä'." Interestingly, there are only two references in al-Ya'qūbī to the abnä', pp. 530-38. 
him are those whom you know from the infantry of Khurasan and its horsemen. He was your master yesterday." ${ }^{159}$ Ṭāhir and 'Abd al-Raḥmān engage in battle outside of Hamadhān. During this battle 'Abd al-Rahmān encourages his men by saying, "Oh Abnā'! Oh, sons of kings, and [those] familiar with swords! Verily they are the 'ajam and are neither the same as people of endurance nor steadfastness." ${ }^{160}$ This is a clear example of the status assertion that the $a b n \bar{a}$ ' were making, defining themselves as an elite in opposition to the other. The battle is hard fought, but ' $\mathrm{Abd}$ al-Rahmān is forced back and he retreats into Hamadhān and Tāhir lays siege. After some time, 'Abd al-Rahmān requests safe passage out of the city with his men. Țāhir grants it, but as they are leaving they ambush Țāhir's forces. ${ }^{161}$ 'Abd alRaḥmān dies during the struggle, but some of his men escape. According to al-Tabarī, they spread the news of the defeat and al-Amin's armies melt away, leaving the path to Baghdad open. It is then a full year before Țāhir reaches Baghdad. After the defeat of 'Alī b. 'Īsā, we begin to see the $a b n \vec{a}^{\prime}$ mentioned more and more frequently until the end of the siege and then only sporadically until al-Ma'mūn comes to Baghdad. At that point the number of references to them declines dramatically.

The threat posed by al-Ma'mūn caused the $a b n \bar{a}^{\prime}$ to coalesce as a collective, but their interests and ties of loyalties were too diffuse to maintain it once the compelling reasons to identify as such were removed. It was not a group present from the beginning of Abbasid rule, bound by a sense of ethnic or national ties. It was the subscription to an identity by a group of military supporters of the Abbasid caliphate based in Baghdad, claiming special ties of loyalty to that caliphate and the caliphal household, intended to supersede the claim that could be made by al-Ma'mūn's forces. It was a claim driven by a threat to position within a social system. Once the cause was lost, al-Amin defeated (and dead) and their positions assumed by al-Ma'mūn's followers, then it was politically and economically difficult to sustain solidarity in an identity that had lost its relevance and meaning. The $a b n \bar{a}$ ' fractured, disintegrated and, after a period of social renegotiation of power roles, the individuals began to coalesce around the new caliph and their identities were reconstituted and adapted.

159. al-Tabarī, $T a^{\prime} r i k h, 3: 827.20-828.1$.

160. Ibid., 829.4-5.

161. Ibid., 831-32. 